\title{
AS ORIGENS DOS DIREITOS HUMANOS AMBIENTAIS
}

\author{
THE ORIGINS OF ENVIRONMENTAL HUMAN RIGHTS
}

\author{
TATIANA DE ALMEIDA FREITAS R. CARDOSO ${ }^{1}$
}

\begin{abstract}
RESUMO: O presente artigo tem como objetivo demonstrar que os Direitos Humanos Ambientais são uma realidade na modernidade, os quais formam uma nova categoria de Direitos, típicos de terceira dimensão. Pretende-se, ao mesmo tempo, perfazer toda a construção desse novel Direito, partindo de uma fundamentação historicista de direitos humanos, com base nos escritos de Hegel e Bobbio. Desta feita, mostrar-se-á que os Direitos Humanos Ambientais são uma construção que envolve uma articulação íntima entre o Direito Internacional dos Direitos Humanos e o Direito Ambiental Internacional, os quais dão origem a um costume internacional - fonte de direito internacional, com força vinculante e obrigatória.

PALAVRAS-CHAVE: Direitos Humanos Ambientais; Direitos de Terceira Dimensão; Historicismo; Costume Internacional.
\end{abstract}

ABSTRACT: The present paper aims at demonstrating that Environmental Human Rights are a fact in modern world, formulating a new category of Rights, typically known as of third dimension. In this sense, a construction of such novel right will be done, departing from a historicist basis of human rights, as developed by Hegel and Bobbio. Thus, it will be shown that Environmental Human Rights are a construction, which involves a minimum of articulation among International Environmental Law and International Law of Human Rights, formulating a new customary rule - source of international law, with a biding and mandatory force.

KEYWORDS: Environmental Human Rights; Third Dimension Rights; Historicism; International Custom.

SUMÁRIO: Introdução; 1. Fundamentação Historicista: de Hegel a Bobbio; 2. A Evolução dos Direitos Humanos em Dimensões; 3. O locus nasciendi do Direito Humano Ambiental; 4. Direito Humano Ambiental como Regra Costumeira; Considerações Finais; Referências Bibliográficas.

\footnotetext{
Artigo recebido em 22.01.2013. Pareceres emitidos em 17.02.2013 e 26.05.2013.

Artigo aceito para publicação em 23.06.2013.

${ }^{1}$ Doutoranda e Mestre em Direito pela Universidade do Vale do Rio dos Sinos (UNISINOS), São Leopoldo/RS, Brasil. Professora de Direito Internacional Público no Centro Universitário Ritter dos Reis (UniRitter), Canoas/RS, Brasil. Professora da Pós Graduação em Direito Ambiental da Feevale, Novo Hamburgo/RS, Brasil. Pesquisadora convidada da Faculdade de Direito da Universidade de Toronto, Toronto/ON, Canadá. tatiana.cardoso@utoronto.ca
} 
SUMMARY: Introduction; 1. Historicist Foundation: from Hegel to Bobbio; 2. The Evolution of Human Rights in Dimensions; 3. The locus nasciendi of Environmental Human Rights; 4. Environmental Human Rights as a Customary Rule; Final Remarks; Bibliography.

\section{INTRODUÇÃO}

Meio ambiente e Direitos Humanos nem sempre caminharam juntos na história da humanidade. Apesar da interdependência do ser humano para com o seu entorno, foi só a partir do agravamento da degradação ambiental, enquanto fenômeno que restringe as liberdades humanas, que esse tema passou a ser debatido na órbita mundial. Afinal, sem um meio ambiente ecologicamente equilibrado e sadio, o homem não se desenvolve dignamente.

A problemática ambiental é um grande obstáculo para o homem enquanto ser, habitante do Planeta Terra. Portanto, emoldurar o meio ambiente enquanto direito humano é o primeiro passo para que essa incoerência cesse, na tentativa de possibilitar a intervenção do Direito para dirimir os conflitos sociais, posto que, dessa forma, o meio ambiente seria um direito existente não só para o indivíduo em si, mas também no ordenamento jurídico doméstico e internacional, o qual demandaria a sua tutela.

Na história da humanidade, a positivação de direitos, isto é, a sua fixação em um documento escrito, sempre foi essencial para induzir à proteção dos Direitos Humanos. Da mesma forma, os direitos dos indivíduos nem sempre foram considerados internacionais em si, sendo fruto de uma conquista da própria humanidade frente às diversas violações sofridas ao longo dos anos, em determinadas conjunturas históricas.

Por isso, primeiramente, cabe explanar as raízes dos direitos do homem garantidos a partir das (r)evoluções sociais, as quais conduzem a sociedade à essa nova etapa mundial em que o meio ambiente está inserido como um direito essencial do indivíduo, nacional e internacionalmente. Parte-se, assim, de uma construção histórica desses direitos, os quais variam conforme a comunidade revela-se e transforma-se.

\section{FUNDAMENTAÇÃO HISTORICISTA: DE HEGEL A BOBBIO}

Para essa fundamentação, mister dizer que os Direitos Humanos brotam em um momento real, determinado e particular no seio da sociedade civil, na essência substancial do homem como parte de uma comunidade. ${ }^{2}$ Quer isto dizer que os direitos basilares, sob este alicerce, vinculam-se aos contextos reais da vida, os quais desdobram-se a partir da progresso da sociedade, considerando prerrogativas comunitárias e costumeiras de cada momento. ${ }^{3}$

\footnotetext{
${ }^{2}$ BILLIER, Jean-Cassien; MARYOLI, Aglaé. A História da Filosofia do Direito. Barueri: Manole, 2005. p. 185-6.

${ }^{3}$ RITCHIE, Daniel. Edmund Burke. New Brunswick: Transaction Publishers, 1990. p. 154-156. No mesmo sentido: SAMPAIO, José Adércio L. Direitos Fundamentais: retórica e historicidade. Belo Horizonte: Del Rey, 2004. p. 38-40.
} 
Logo, afasta-se qualquer perspectiva de Direitos Humanos enquanto bens primários comuns aos homens, atribuídos a priori aos seres racionais, isto é, prévio a qualquer lei positiva ou momento histórico. ${ }^{4}$ Embora esses bens fundamentais fazerem parte da própria historicidade humana, seguindo a tese historicista-sociológica, os direitos são construídos pelas necessidades concretas de um determinado período. E encontramos em Hegel e, sobretudo, em Bobbio os fundamentos para corroborar esse posicionamento.

A filosofia da história de Hegel aceita a ideia que o homem é uma construção histórica, coletiva e social, que transcende a esfera privada. ${ }^{5}$ Hegel, ao falar da natureza humana, não esconde que ela é algo permanente, porém, exprime que o seu conceito deve sempre adaptar-se aos homens conforme os períodos históricos que eles vivenciam em comunidade, os quais podem sofrer infinitas modificações. ${ }^{6}$ Nesse sentido, o direito também sofreria alteração, eis que, segundo a tese hegeliana, este igualmente acompanha o desenrolar da história de cada grupo social. ${ }^{7}$

Quer isso dizer que a posição hegeliana deposita na história e nas características da própria sociedade o desencadear racional do direito (incluindo os direitos fundamentais). Assim sendo, o passar do tempo, conforme a tese do filósofo alemão, nas palavras de Helder Andrade, "deve ser entendido como um continuum e irreversível articulador da ação humana, porém, não como um todo homogêneo e desarticulado, mas um processo de articulação das fases e períodos da história, garantindo a possibilidade do entendimento de todo o processo histórico". ${ }^{8}$ Hegel nega qualquer desdobramento empírico, permanente e incoerente com as realidades humanas. ${ }^{9}$

As recentes defesas das propostas historicistas estão fundadas em Norberto Bobbio, na percepção de que o conteúdo dos Direitos Humanos continua a se alterar "com a mudança das condições históricas, ou seja, dos carecimentos e dos interesses, das classes no poder, dos meios disponíveis para a realização dos mesmos e das transformações técnicas". ${ }^{10} \mathrm{Em}$ outros termos, esse autor afirma que o conjunto de direitos básicos é extremamente variável, não podendo estar confinado a um determinado espaço temporal e nunca ser alterado. ${ }^{11}$

\footnotetext{
${ }^{4}$ Essa seria a fundamentação a partir do Direito Natural, encontrada em John Finnis, por exemplo. Para esse autor, ver: FINNIS, John. Natural Law and Natural Rights. Oxford: Oxford University Press, 1980; ENGELMANN, Wilson. Direito Natural, Ética e Hermenêutica. Porto Alegre: Livraria do Advogado, 2007.

${ }^{5}$ BILLIER; MARYOLI. Op. Cit., p. 184.

${ }^{6}$ HEGEL, Georg. A Razão na História. São Paulo: Centauro, 2001. p. 62.

${ }^{7}$ VAZ, Henrique C. Lima. Escritos de Filosofia IV. São Paulo: Loyola, 2006. p. 395-400.

${ }^{8}$ ANDRADE, Helder N. Hegel e Vico: o sentido da história. Argumentos - Revista de Filosofia. Fortaleza, a. 1, no 1, p. 28-35, 2009. p. 34.

${ }^{9}$ SAID, Edward W. Reflexões sobre o Exílio e outros ensaios. São Paulo: Companhia das Letras, 2003. p. 72-3; DOUZINAS, Costas. The End of Human Rights. Portland: Hart Publishing, 2000. p. $113,345-346,377$.

${ }^{10}$ BOBBIO, Norberto. A Era dos Direitos. Trad. Carlos Nelson Coutinho. Rio de Janeiro: Campus, 1992. p. 18.

${ }^{11}$ Idem. Ibidem.
} 
O professor italiano sustenta que o historicismo é "toda concepção da realidade, de modo particular a realidade humana, às vezes contraposta à realidade da natureza, como movimento, desenvolvimento, processo em direção a um fim último, alcançável por meio de uma série de momentos concatenados um ao outro", corroborando para uma construção de "uma nova dimensão da realidade", fulcrada nas particularidades do desencadear da história, na flexibilidade do direito e realmente distanciada do jusnaturalismo. ${ }^{12}$

Ao explanar a posição Bobbiana, Mary Jane Spink expõe que "os vários direitos emergem de condições sociais peculiares e, portanto, não são estabelecidos ao mesmo tempo", variando conforme abrolham os movimentos e lutas sociais na história da comunidade. ${ }^{13}$ Nas suas palavras, Bobbio confirma: os Direitos Humanos "são direitos que cabem ao homem enquanto homem" na sociedade, pois "nascem quando devem ou podem nascer", por força de um momento histórico. ${ }^{14}$ Por conseguinte, é visível que o italiano advoga por uma "visão sociológica do direito (humano) que, por surgir na e se dirigir à sociedade, não pode ter seus princípios e tutelas dela desvinculados". ${ }^{15}$

Afinal, segundo a doutrina de Bobbio um movimento sustenta-se quando interligado a um momento em específico na história. Quer isto dizer que os direitos vão emergindo conforme a sociedade evolui, nunca sendo estática, afinal, se assim fosse, não poderiam emergir novos direitos, tais como se pretende, com a classificação do Direito Humano Ambiental.

Para tanto, não ignorar as mudanças, reconhecendo os movimentos do mundo hodierno é essencial. ${ }^{16} \mathrm{E}$ é por isto que ele advoga pela teoria historicista - pois permite a transformação do conteúdo, não sendo fixo e imutável. Em seus próprios termos:

[O]s direitos dos homens são direitos históricos, que emergem gradualmente das lutas que o homem trava por sua própria emancipação e das transformações das condições de vida que essas lutar produzem.

[...] Os direitos ditos humanos são o produto não da natureza, mas da civilização humana; enquanto direitos históricos, eles são mutáveis, ou seja, suscetíveis de transformação e de ampliação. ${ }^{17}$

\footnotetext{
${ }^{12}$ BOBBIO, Norberto. O Problema da Guerra e as Vias da Paz. São Paulo: UNESP, 2003. p. 85.

${ }^{13}$ SPINK, Mary Jane P. A Saúde na Encruzilhada entre Biopolítica e Bioeconomia. In: RIBEIRO, Maria Auxiliadora; BERNARDES, Jefferson de Souza; LANG, Charles Elias. A Produção na Diversidade: compromissos éticos e políticos em psicologia. São Paulo: Casa do Psicólogo, 2007. p. 57.

${ }_{14}^{14}$ BOBBIO. (1992). Op. Cit., p. 6 e 17.

${ }^{15}$ FURTADO, Fernanda Andrade. Direitos Humanos, Ética Ambiental e o Conflito entre Direitos Fundamentais. Revista da Fundação Escola Superior do Ministério Público do Distrito Federal e Territórios. Brasília, a. 11, p. 50-110, set. 2003. p. 50-51.

${ }^{16}$ BOBBIO, Norberto. Elogio da Serenidade e outros Escritos Morais. São Paulo: UNESP, 2000. p. $145-146$.

${ }^{17}$ BOBBIO. (1992). Op. Cit., p. 32.
} 
$\mathrm{O}$ argumento das correntes historicistas, nesse sentir, busca determinar que os Direitos Humanos, enquanto produtos da modernidade, podem sempre ser aprimorados, desenrolando-se ao longo da história, sendo impassíveis de um controle puramente empírico e fechado, os quais seriam elucubrados apartados da realidade social. ${ }^{18}$ Noutra palavra, o conteúdo desses direitos não poderia ser sob hipótese alguma limitados a um conjunto único inerte, visto que "condicionados pela defesa da personalidade humana diante dos poderes ou métodos que cada tempo ou situação a ameace", com base em suas características comunitárias. ${ }^{19}$

Inclusive, nos termos de Bobbio, o Direito Humano sob o panorama da inalterabilidade poderia até mesmo ser "um pretexto para defender posições conservadoras". ${ }^{20}$ Ou seja, de não aceitar o meio ambiente enquanto Direito Humano - o qual, porém, já está arraigado enquanto um costume internacional e um direito constitucional. ${ }^{21}$

Destarte, partindo dessa fundamentação, passamos a traçar a procedência e a consequente proliferação dos Direitos Humanos, a partir das suas alterações e aperfeiçoamentos, a fim de demonstrar que a sociedade sempre reage aos "males" que lhe aflige, de modo que a Tragédia dos Baldios faz emergir um novo direito - o Direito Humano Ambiental. Nessa esteira, a "positivação" dos Direitos Humanos está distribuída em três momentos históricos, os quais ajudam a explicar a estruturação da concepção moderna e plural dos direitos básicos do homem em suas três dimensões. ${ }^{22}$

\footnotetext{
18 THOMAS, Brook. The New Historicism and other old-fashioned topics. Princeton: Princeton University Press, 1991. p. 75.

${ }^{19}$ SAMPAIO, José Adércio L. Direitos Fundamentais: retórica e historicidade. Belo Horizonte: Del Rey, 2004. p. 108.

${ }^{20}$ BOBBIO. (1992). Op. Cit., p. 22.

${ }^{21}$ Frisa-se que a utilização de "direito constitucional" remonta ao próprio direito fundamental amparado pelo direito interno dos países, o qual é o oposto de direito humano (pois internacional). Todavia, opta-se por essa nomenclatura para não confundir o ledor, afinal, utiliza-se nessa parte direito humano e direito fundamental enquanto sinônimos de direitos da pessoa humana, sem a distinção entre doméstico ou mundial.

${ }^{22}$ Oportuno dizer que Bobbio adota o sistema geracional até a quarta geração (direitos referentes à biotecnologia e ao patrimônio genético, os quais, por incipientes e sem definição doutrinaria pacífica, não serão abordados). Salienta-se, do mesmo modo, que ele utiliza da nomenclatura "gerações" e não dimensões. Opta-se pela segunda dado o fato que a utilização da primeira poderia expressar a ideia de sobreposição de direitos através do processo histórico, o qual não é o caso. Na verdade, Bobbio apenas afirma que os Direitos Humanos, ao emergirem, tornam-se limitadores dos direitos anteriores. Explica o autor italiano que, ao passo que os direitos sociais aumentam (definição trazida na sequencia do trabalho), os direitos civis e políticos, isto é, os direitos individuais, diminuem. Exemplificamos com a ideia de que hodiernamente advogamos por mais proteção à atos terroristas, porém, para que tal ocorra, permitimos a invasão de nossa casa ou correio eletrônico, sem nossa autorização por parte do governo - tal como ocorre nos EUA. Inclusive, segundo o autor, é por isso que há certa resistência à positivação (aceitação) de novos direitos. BOBBIO. (1992). Op. Cit., p. 20-22. Cf. também: SCHAFER, Jairo. Classificação dos Direitos Fundamentais: do sistema geracional ao sistema unitário. Porto Alegre: Livraria do Advogado, 2005. p. 38-40.
} 


\section{A EVOLUÇÃO DOS DIREITOS HUMANOS EM DIMENSÕES}

O primeiro período que se destaca está assentado nas lutas do ser humano perante os abusos dos monarcas e aristocratas, tendo como primeiro ponto marcante a promulgação da Magna Carta Liberatum, no ano de 1215 na Baixa Idade Média. Esse documento foi considerado "o ponto de referência para alguns direitos e liberdades civis clássicos", pois apresenta traços primitivos de liberdade, protegidos pela primeira vez sob a forma escrita, como bem aponta Ingo Wolfgang Sarlet. ${ }^{23}$

Ademais, ainda inserido nesse mesmo momento da história, estão as leis inglesas Petition of Rights (1628), ${ }^{24}$ Habeas Corpus $(1679)^{25}$ e Bill of Rights (1688), ${ }^{26}$ as quais marcam "o início da limitação do poder do Estado", permitindo o indivíduo ser livremente, sem demasiadas restrições de direitos, principalmente no que tange as liberdades de ir e vir. ${ }^{27}$ Não só foi relevante a participação da Inglaterra para a evolução dos Direitos Humanos, como também foi a de suas colônias nos Estados Unidos, as quais apresentaram acentuada importância para a proteção das liberdades clássicas do homem.

Nomeadamente, o marco além-mar está situado na Carta da Virgínia, redigida em junho de 1776, vez que foi a pioneira dentre os documentos coloniais produzidos naquela localidade que explicitamente abarcada a proteção de direitos individuais específicos, como o direito à vida, à propriedade, à liberdade, à felicidade e à igualdade - realmente resguardando os direitos da individualidade humana. ${ }^{28}$

Posteriormente a este documento, outros emergiram dentre as 13 colônias britânicas ${ }^{29}$ culminando na Declaração de Independência dos Estados Unidos

\footnotetext{
${ }^{23}$ SARLET, Ingo W. Dignidade da Pessoa Humana e Direitos Fundamentais na Constituição Federal de 1988. Porto Alegre: Livraria do Advogado, 2009. p. 49.

${ }^{24}$ Bernard Schwartz afirma que "a Petição de Direito, embora aprovada pelo Parlamento e não apenas como um mero protesto [...] era apenas um documento declaratório", contra os abusos e prerrogativas do Monarca. SCHWARTZ, Bernard. Os Grandes Direitos da Humanidade: The Bill of Rights. Trad. A. B. Pinheiro de Lemos. Rio de Janeiro: Forense Universitária, 1979. p. 22-23; INGLATERRA. Petition Of Right. 1628.

${ }^{25}$ Fabio Konder Comparato atesta a importância histórica do habeas-corpus, a qual constituiu-se "no fato de que essa garantia judicial, criada para proteger a liberdade de locomoção, tornou-se a matriz de todas as que vieram a ser criadas posteriormente, para a proteção de outras liberdades fundamentais". COMPARATO, Fábio Konder. A Afirmação Histórica dos Direitos Humanos. 5. ed., São Paulo: Saraiva, 2007. p. 89; INGLATERRA. Lei de Habeas Corpus. 1679.

${ }^{26}$ Essa lei limita as prerrogativas enquanto governador do Estado, exigindo maior participação do parlamento, assegurando a este sua independência funcional, prosperando para uma separação de poderes, a qual, na concepção de Fábio Konder Comparato, é "indispensável para as liberdades civis". Idem. p. 49-50; INGLATERRA. Bill Of Rights. 1688.

${ }^{27}$ MAGALHÃES, José Luiz Quadros de. Direitos Humanos: sua história, sua garantia e a questão da indivisibilidade. São Paulo: Juarez de Oliveira, 2000. p. 19.

${ }^{28}$ SCHWARTZ. Op. Cit., p. 35; ESTADOS UNIDOS. Carta da Virgínia. 1776.

${ }^{29}$ As declarações que seguiram a Carta da Virgínia foram: a Declaração de Direitos da Pennsylvania, de Delaware, de Maryland e de Vermont. Já os estados de New Jersey, de Georgia, de New York e da South Carolina, ao invés de optarem por uma declaração, fizeram constar tais direitos dentro de suas novas constituições estatais. Idem. p. 75-82.
} 
da América em julho 1776 e a própria Constituição Norte-Americana de 1787, onde apregoou-se "a igualdade entre os homens, considerados titulares de certos direitos inalienáveis como a vida, a liberdade e a busca da felicidade" - comumente conhecidos como direitos inerentes ao homem, os quais nunca antes haviam sido garantidos sob o viés constitucional, como aduz o ilustre ministro Enrique Ricardo Lewandowski. ${ }^{30}$

Essas convicções, estendidas aos franceses revolucionários de 1789 , serviram como fonte de inspiração para o reconhecimento (neste país) da liberdade, igualdade e fraternidade como direitos comuns a todos os cidadãos, invariáveis em meio a revoluções, instituídos com intuito de "proteger o homem contra os atos [opressores] do Governo", tal como aponta Manoel Gonçalves Ferreira Filho ${ }^{31}$ acerca da conhecida Declaração dos Direitos do Homem e do Cidadão. ${ }^{32}$

Com efeito, esse primeiro período histórico é assinalado como o momento em que os seres humanos passam a ter a definitiva consagração de certas liberdades civis e políticas como inalienáveis e invioláveis, pois requerida pelos homens em meio as repetitivas violações unilaterais cometidas pelos governantes, sobre a qual estes não poderiam impor suas vontades. Noutros termos, é comumente designado como a era de positivação dos direitos de primeira dimensão, em que os Direitos passam a ser usufruídos contra o Estado - exigindo um afastamento deste para a correta fruição.

O segundo momento histórico marcante para explicar a edificação do Direito Humano moderno resta nas transições ocorridas durante o século XIX, haja vista "o impacto da industrialização e os graves problemas econômicos" ocasionados pela política de conservação formal da liberdade e da igualdade, as quais geraram "amplos movimentos reivindicatórios" em prol de uma atuação mais positiva do Estado para o efetivo gozo dos direitos inerentes ao ser humano. ${ }^{33}$

Deste entendimento que surgem a Constituição Mexicana (1917) e a Constituição de Weimar (1919), amparadas por essa nova tendência de relação entre Estado e indivíduo, preocupada com a garantia efetiva dos direitos básicos de todos os cidadãos, mormente no que compete à igualdade (material) entre eles. ${ }^{34}$ Neste modelo de ordenamento jurídico, os direitos econômicos e sociais passam a ganhar espaço entre as reivindicações sociais,

30 LEWANDOWSKI, Enrique Ricardo. Proteção dos Direitos Humanos na Ordem Interna e Internacional. Rio de Janeiro: Forense, 1984. p. 48; ESTADOS UNIDOS. Declaração de Independência. 1776; ESTADOS UNIDOS. Constituição Federal. 1787.

${ }^{31}$ FERREIRA FILHO, Manuel Gonçalves. Curso de Direito Constitucional. 24. ed., São Paulo: Saraiva, 1997. p. 22.

${ }^{32}$ FRANÇA. Declaração dos Direitos do Homem e do Cidadão. 1789. Para detalhes, ver: COMPARATO. Op. Cit., p. 151, 158 e 159; e ANDRADE, José Carlos Vieira de. Os Direitos Fundamentais na Constituição Portuguesa de 1976. Coimbra: Livraria Almedina, 1987. p. 14.

${ }^{33}$ SARLET. Op. Cit., p. 56.

${ }^{34}$ SCHAFER. Op. Cit., p. 27; MEXICO. Constituição Federal. 1917; ALEMANHA. Constituição de Weimar. 1919. 
os quais são realizados por meio de políticas públicas, permitindo, desta forma, a concretização desses direitos também inerentes ao homem.

Isso, pois, percebe-se que para a completa realização do ser humano, o Estado não pode permanecer alheio a todas as situações fáticas, devendo criar meios apropriados de subsistência, de trabalho e de outras condições, para transformar em realidade alguns dos direitos do homem, cuja tarefa não cabe ao próprio individuo. ${ }^{35}$ Desta feita, constrói-se um entendimento de que o Estado é garantidor de direitos e que cabe a sociedade exigir contraprestações aos seus governantes para a concretização dos mesmos. ${ }^{36}$

Assim, o Walfare State é o segundo momento histórico marcante, cuja característica está na sociabilidade humana. Afinal, os cidadãos percebem a necessidade de intervenção estatal para a sólida implementação de certos comandos jurídicos, na tentativa de acentuar a igualdade entre os homens, os quais não seriam propiciados de forma negativa, pela inação do Estado. ${ }^{37}$ Por isso são conhecidos como liberdades positivas ou Direitos Humanos de segunda dimensão, vez que exigem uma maior participação do Estado na vida do ser humano, para garantir direitos como saúde, trabalho, lazer, vida em sociedade digna, etc.

Com efeito, a transformação da sociedade é evidente, ao passo que de um momento em que buscou restringir o campo de ação do Estado, frente às violações que sofria deste, emergem outros fatos históricos os quais demandam uma atenção maior do próprio governo para com o ser humano para que este se realize. As transgressões aos limites do homem afloravam-se, numa evidente proliferação de direitos a partir do desenvolvimento social face às restrições vislumbradas no ser/agir humano.

Por força de seu caráter histórico-evolucionista, o progresso da comunidade não cessa. E com novas ambições, abrolham outras violações, distintas daquelas antes vislumbradas, a qual faz emergir uma busca pela materialização de novos direitos. Anota Norberto Bobbio sobre a abertura à nova dimensão - a terceira dimensão - dos Direitos Humanos:

O caminho contínuo, ainda que várias vezes interrompido, da concepção individualista da sociedade procede lentamente, indo do reconhecimento dos direitos do cidadão de cada Estado até o reconhecimento dos direitos

\footnotetext{
${ }^{35}$ BONAVIDES, Paulo. Curso de Direito Constitucional. 11. ed., São Paulo: Malheiros, 2001. p. 343.

${ }^{36}$ Interessante notar que dessas discussões neste momento específico da história é que foi edificada a Organização Internacional do Trabalho ('OIT'), por força do Tratado de Versalhes, em 1919 (a qual já era negociada desde 1890). Esse fato é muito relevante, pois é uma das primeiras manifestações quanto a necessidade de proteção uniforme ao trabalhador no domínio internacional - o que faz germinar a própria ideia de coletividade, enquanto interesse comum à humanidade. FERREIRA FILHO, Manoel Gonçalves. Direitos Humanos Fundamentais. 13. ed., São Paulo: Saraiva, 2011. p. 65-69.

${ }^{37}$ MORAIS, José L. Bolzan. As Crises do Estado e da Constituição e a Transformação Espacial dos Direitos Humanos. Porto Alegre: Livraria do Advogado, 2002. p. 35.
} 
do cidadão do mundo [...]; a partir do direito interno de cada Estado, através do direito entre os outros Estados, até o direito cosmopolita. ${ }^{38}$

Desta banda, se aquelas duas dimensões historicamente constituídas, tinham o condão de proteger o indivíduo e garantir-lhe formalmente e materialmente os seus direitos, ainda que dentro dos limites dos Estados soberanos, o intuito e os ideais das novas tutelas que surgem a partir do final da Segunda Guerra Mundial são verdadeiramente diferentes, pois almejadas pela coletividade mundial. Como uma resposta as "monstruosas violações cometidas por Hitler" e "na crença de que essas violações possam ser prevenidas" no futuro, como mostra Thomas Buergenthal, essa nova dimensão tem como fito buscar evitar novas transgressões, as quais, na modernidade, tornam-se intercontinentais. ${ }^{39}$

Neste período da história, portanto, os Direitos Humanos passaram a ser caracterizados como um tema de legítimo interesse da comunidade internacional, ligados à finalidade de emancipar os indivíduos (na sua pluralidade) de toda e qualquer violação que não os permita serem livres e iguais - direitos considerados necessários para o cidadão realizar-se enquanto habitante de uma única sociedade (mundial). ${ }^{40}$ Por causa desta preocupação geral, os Direitos Humanos passaram de uma competência restrita a soberania de um Estado à competência mundial, em que todos os países mostram-se engajados na sua proteção.

Inaugurou-se, a partir disso, uma nova etapa nas relações internacionais: o surgimento da Organização das Nações Unidas ('ONU') - uma organização internacional criada em 1945, com o propósito de estabelecer um foro permanente de diálogo entre as nações para o mantenimento da paz mundial. Sob seu escopo, o movimento inicial foi a adoção da Carta das Nações Unidas, a qual além de estabelecer o funcionamento básico da referida organização, determina a observação geral dos Direitos Humanos e das liberdades dos cidadãos, os quais aparecem por várias vezes nos dispositivos deste documento, seja por menção direta ou indireta, reconhecendo-se, desta forma, que tais direitos "ultrapassam as fronteiras da soberania de cada Estado", como expõe Heiner Bielefeldt. ${ }^{41}$

É neste contexto que Douglas César Lucas assevera que os Estados "passaram a pautar sua ação externa pelo imperativo da paz e pela proteção dos Direitos Humanos", porém, sem que houvesse ainda um documento no

\footnotetext{
${ }^{38}$ BOBBIO. (1992). Op. Cit., p. 4.

${ }^{39}$ BUERGENTHAL, Thomas. International Human Rights in a Nutshell. 3. ed., New York: West Publishing, 2002. p. 27.

${ }^{40}$ PIOVESAN, Flávia. Temas de Direitos Humanos. São Paulo: Max Limonad, 1998. p. 49-50; MALONE, Linda A. International Human Rights. St. Paul: West Group, 2003. p. 18.

41 BIELEFELDT, Heiner. Filosofia dos Direitos Humanos. Trad. Dankwart Bernsmüller. São Leopoldo: UNISINOS, 2000. p. 12.
} 
plano internacional que colacionasse todos os direitos a serem tutelados. ${ }^{42}$ Logo, ligada à finalidade de proteger e mundializar estas regras e de formar um "sistema normativo internacional de proteção", conforme menciona Flávia Piovesan, os países acabam deliberando, na então novíssima Assembleia Geral das Nações Unidas ('AGNU'), acerca de uma resolução que abarcasse esses direitos considerados basilares. ${ }^{43}$

Assim, é adotada a Declaração Universal dos Direitos Humanos ('DUDH'), aprovada em 10 de dezembro de 1948, tornando ainda mais palpável a ideia de o indivíduo ser protegido internacionalmente. ${ }^{44}$ Louis Henkin confirma a importância desse documento, destacando o seu papel em "estipular um mínimo de direitos a serem garantidos por cada Estado através de seu sistema político e legislativo interno", demonstrando a necessidade de cooperação e comprometimento das nações para assegurarem os direitos básicos aos indivíduos em seus territórios, mundialmente. ${ }^{4}$

Segundo Danielle Annoni, esta Declaração é considerada o "marco de positivação dos direitos humanos no plano internacional", posto que nela estão assentados os direitos de primeira, segunda, e alguns noveis direitos terceira dimensão. ${ }^{46}$ Especificamente, os direitos de terceira dimensão são os direitos relativos à solidariedade e a fraternidade, mais conhecidos como direito dos povos, cuja titularidade é coletiva.

Quer isto dizer que, a partir desse período, não se fala mais em conquistar direitos para um homem ou uma classe, mas para todos os indivíduos, sob ameaça de perder seu sentido. ${ }^{47}$ Abordando essa matéria, Almir de Oliveira explica que as transgressões de Direitos Humanos, hodiernamente, ocorrem tanto no âmbito nacional, "quando ocorrem nos limites da circunscrição territorial de um Estado", como também no âmbito internacional, consistindo em "violações que ultrapassam os limites territoriais dos Estados" - afetando a coletividade em seu âmago. ${ }^{48}$

Em virtude disso, o desejo de reconstruir e manter a sociedade global sem violações grosseiras às liberdades básicas dos homens, as quais não ocorrem apenas em uma localidade, difundiu-se, isto é, internacionalizou-se. Logo, não há como negar o valor histórico dessa Organização e, sobretudo,

\footnotetext{
42 LUCAS, Douglas César. Os Direitos Humanos como Limite à Soberania Estatal: Para uma cultura político-jurídica global de responsabilidades. In MENEZES, Wagner (Coord.). Estudos de Direito Internacional. Vol. IX. Curitiba: Juruá, 2007. p. 457-470.

${ }^{43}$ PIOVESAN. Op. Cit., p. 49-50.

${ }^{44}$ AGNU. Resolução 217 A (III). 1948.

45 HENKIN, Louis. International Law and the Behavior of Nations. Recueil des Cours de l'Academie de Droit International. Hague, v. 114, nº 1, p. 171-279, 1965. p. 275-6.

${ }^{46}$ ANNONI, Danielle. O Legado da Declaração Universal dos Direitos Humanos das Nações Unidas. Revista lus Gentium. Curitiba. A. 1, n² 2, p. 73-86, jul./dez. 2007. p. 82.

${ }^{47}$ CARDOSO, Tatiana de A. F. Direitos Humanos no Século XXI: a tutela das novas categorias e a sua (não) efetividade na era do risco. Anais da III Mostra de Pesquisa de Pós-Graduação - MIC. Passo Fundo: IMED, 2010. p. 6.

${ }^{48}$ OLIVEIRA, Almir de. Curso de Direitos Humanos. Rio de Janeiro: Forense, 2000. p. 233-236.
} 
desta Declaração, constituindo a base do Direito Internacional dos Direitos Humanos. Afinal, a partir delas que os direitos de terceira dimensão, ao lado dos demais direitos já consagrados na história, são lançados para o mundo.

São exemplos dos direitos difusos positivados nesses documentos o direito da não intervenção, da paz mundial, da solução pacífica de controvérsias, da cooperação e da autodeterminação dos povos, os quais, por tratarem-se de direitos construídos a partir do desenrolar da sociedade, não apresentam um rol taxativo, estando sujeitos a uma maior diversificação. Na verdade, conforme a opinião da própria ONU, por abarcar todos esses novos anseios de ordem coletiva, a Carta e a Declaração servem como fonte de inspiração para a preparação de instrumentos internacionais acerca de outros Direitos Humanos, na medida em que outras reivindicações proliferarem-se no seio da comunidade. $^{49}$

Neste contexto, considerando a Tragédia dos Bens Comuns ${ }^{50}$, a qual começou a gerar uma preocupação maior à comunidade internacional a partir da década de 1960, é que a sociedade internacional começa a discutir acerca do meio ambiente enquanto Direito (autônomo), iniciando a sua caminhada para classificá-lo como Direito Humano difuso. Os problemas mundiais, como a poluição marinha, o buraco da camada de ozônio, a finitude dos recursos naturais e o aquecimento global tornam as discussões sobre o meio ambiente em voga, clamando por uma tutela (de direito humano) específica. Todavia, a sua inclusão enquanto Direito Humano não foi simples, mas, uma construção genuinamente histórica, a qual vem adquirindo maturidade no plano internacional. ${ }^{51}$

\section{O LOCUS NASCIENDI DO DIREITO HUMANO AMBIENTAL}

Durante a história, o planeta sempre soube regenerar-se, afastando os males que the impactavam de algum modo natural. Entretanto, com a incisiva e constante ação humana no meio ambiente, as tragédias ambientais tornaram-se cada vez mais corriqueiras. ${ }^{52}$ Atualmente, o planeta já está além da sua capacidade máxima, denotando um cenário de esgotamento dos próprios recursos naturais, haja vista que a quantidade disponível dos bens

\footnotetext{
${ }^{49}$ ONU. Las Naciones Unidas y Los Derechos Humanos. Nueva York: ONU, 1979. p. 28.

${ }^{50}$ Teoria pensada pelo sociólogo norte-americano Garret Hardin, que problematiza a situação da inexistência de regras que governem os bens comuns, direcionando a sociedade à individualização e a busca da total exploração dos recursos naturais, maximizando os seus lucros das partes envolvidas, independentemente do que isso possa gerar aos demais membros da comunidade mundial (no sentido de sobrecarregar e destruir o meio ambiente). Cf. HARDIN, Garret. Tragedy of the Commons. Science. v. 162, no 3859, p. 1243-1248, dec. 1968.

${ }^{51}$ MAZZUOLI, Valério de O.; TEIXEIRA, Gustavo de Faria. O Greening do Sistema Interamericano de Direitos Humanos. Revista Científica Sensus: Direito. Manaus, no 5, v. 2, p. 1-21, jul./dez. 2012. p. 7.

${ }^{52}$ A ação humana contribuiu diretamente para tal destruição do meio ambiente, tendo intensamente alterado a biosfera em menos de $0,000002 \%$ da idade total da Terra. POJMAN, Louis P. Global Environmental Ethics. Mountain View: Mayfield, 2000. p. 1.
} 
ambientais ao redor do globo é menor do que a desejada para suprir as necessidades dos países desenvolvidos e em desenvolvimento. ${ }^{53}$

Nesse sentido, não obstante os problemas relativos ao ambiente não serem hodiernos, a potencial ocorrência de um colapso planetário na atualidade torna o seu combate imperioso, o que naturalmente conduz à necessidade de reconhecer-se o meio ambiente enquanto um Direito Humano para sua melhor tutela. Afinal, esse fato não pode ser tratado apenas dentro dos limites dogmáticos do próprio Direito Ambiental (Internacional), sendo necessário encontrar um campo que reconheça a sua abrangência e importância, haja vista que o impacto que tal causa na vida dos seres humanos é proeminente, sobretudo, quando apresentado a partir das limitações geradas na liberdade do homem de locomover-se livremente ${ }^{54}$ e na própria saúde dos cidadãos ${ }^{55}$.

Nesse viés, como bem trouxe a professora portuguesa Carla Amado Gomes, José J. Gomes Canotilho já anotava que "o jurista de ambiente deve confessar a sua humildade e reconhecer que sem o amparo de outros ramos do direito não é possível edificar um corpus teórico suficientemente autónomo para abarcar todas as multidimensionalidades dos problemas ambientais". ${ }^{56}$ Em outras palavras, é certo que o combate às questões ambientais não poderia estar limitado a uma disciplina apenas, esgotando-se em uma análise singular que não abarcaria toda a complexidade e abrangência do tema.

Logo, o local encontrado para que as diferentes lógicas envolvidas na questão ambiental possam reunir-se é no campo dos Direitos Humanos, precisamente pelo fato de os direitos inerentes à pessoa humana ser um assunto que perpassa transversalmente todas as áreas do Direito, seja domesticamente ou internacionalmente, estabelecendo limites por intermédio

\footnotetext{
${ }^{53}$ SNIDAL, Duncan. The Politics of Scope: endogenous actors, heterogeneity and institutions. In: KEOHANE, Robert O.; OSTROM, Elinor. Local Commons and Global Interdependence: heterogeneity and cooperation in two domains. London: SAGE Publications, 1995. p. 50.

${ }_{54}$ Os problemas de liberdade estão assentados na questão da crescente onda de refugiados e deslocados ambientais, os quais são forçados a deixar o lugar onde habitam em virtude dos problemas ambientais locais e/ou mundiais quando causam danos irreversíveis ao seu habitat, transformando-o em impróprio para a continuidade da vida, pois insustentável em meio à degradação (como é o caso da llha de Tuvalu no Pacífico). Estima-se que mais de 25 milhões de pessoas encontram-se nessa situação. MYERS, Norman. Environmental Refugees: a growing phenomenon of the 21 century. Philosophical Transactions of the Royal Society. v. 357, p. 609-613, abr. 2002. p. 609.

${ }^{55}$ Nas palavras de Tadeu Migoto Filho e Ana Cláudia Pinheiro: "a íntima relação entre direito à saúde e a preservação ambiental se evidencia no fato de que a maioria das lesões perpetradas contra a natureza, pela poluição, denigre a saúde humana, muitas vezes, inclusive, de forma irreversível". MIGOTO FILHO, Tadeu; PINHEIRO, Ana Cláudia. Enfoque Ambiental dos Direitos Humanos. In: MENEZES, Wagner (Coord.). Estudos de Direito Internacional. Vol. XVI. Curitiba: Juruá, 2009. p. 410.

${ }^{56}$ CANOTILHO, J. J. Gomes. Juricidização da Ecologia ou Ecologização do Direito apud GOMES, Carla Amado. O Ambiente como Objecto e os Objectos do Direito do Ambiente. Disponível em: <http://egov.ufsc.br/portal/sites/default/files/anexos/19332-19333-1-PB.pdf>. Acesso em $10 \mathrm{mar}$. 2013.
} 
do seu reconhecimento e articulando conceitos mínimos que devem ser promovidos e respeitados em âmbito universal em prol do bem-estar de todos. ${ }^{57}$

Sob esse aspecto, o ilustre Juiz da Corte Internacional de Justiça, Antônio Augusto Cançado Trindade afirma que:

Embora tenham os domínios da proteção do ser humano e da proteção ambiental sido tratados até o presente separadamente, é necessário buscar maior aproximação entre eles, porquanto correspondem aos principais desafios de nosso tempo, a afetarem em última análise os rumos e destinos do gênero humano. ${ }^{58}$

Do mesmo modo, Sandra Akemi S. Kishi traz à baila a explicação para o meio ambiente ser abarcado pelos Direitos Humanos:

[...] essa perspectiva das inter-relações entre a proteção dos direitos humanos e a proteção ambiental, dificilmente a visão antropocêntrica pode ser descartada, pois ao se tutelar o valor intrínseco da Natureza estão sendo tutelados os humanos, que dela dependem para viver. A Humanidade, atual e futura, é o sujeito ativo da proteção ao meio ambiente equilibrado. ${ }^{59}$

Deste modo, pode-se afirmar que o Direito Humano Ambiental é oriundo não só do Direito Ambiental em si, como também dos Direitos Humanos quando da percepção dos impactos na vida humana das implicações da degradação ambiental extrema, as quais se materializam ao longo da história. Nestes casos, o Direito Ambiental (Internacional) e o Direito Internacional dos Direitos Humanos unem-se para combater o problema ambiental ${ }^{60}$, os quais fazem por meio deste novo direito.

Isso, pois, a gravidade das consequências ambientais atinge o ser humano duplamente, na qualidade de vida, como direito ao meio ambiente, e na sua pessoa (em sua vida em si), enquanto violação de direitos humanos. Klaus Bosselmann compartilha dessa posição, afirmando que "tanto os direitos

\footnotetext{
${ }^{57}$ SHELTON, Dinah. Environmental Rights. In: ALSTON, Philip. (ed.). People's Rights. New York: Oxford University Press, 2001. p. 195.

${ }^{58}$ CANÇADO TRINDADE, Antônio A. Direitos Humanos e Meio Ambiente: paralelo dos sistemas de proteção internacional. Porto Alegre: SAFE, 1993. p. 75.

59 KISHI, Sandra Akemi S. A Proteção da Biodiversidade: um direito humano fundamental. In Desafios do Direito Ambiental no Século XXI: estudos em homenagem a Paulo Affonso Leme Machado. São Paulo: Malheiros/IEDC, 2005. p. 711.

${ }^{60}$ Para fins didáticos, cumpre dizer que o Direito Ambiental (Internacional) busca tutelar o meio ambiente em si, evitando danos ao ecossistema, assegurando-lhe a sua continuação a consequente o prosseguimento da vida humana, justamente pelos processos ecológicos planetários suportarem-na; já o Direito Internacional dos Direitos Humanos tem como escopo o controle de violações contra os seres humanos, não permitindo que eles sejam atacados na sua intimidade aonde quer que estejam, impondo um limite universal às várias condutas dos atores internacionais.
} 
humanos quanto a legislação ambiental são necessários para proporcionar melhores condições de vida para os seres humanos". ${ }^{61}$

Essa relação também reflete o entendimento da Corte Internacional de Justiça ('ClJ'), a qual se manifestou acerca disso no caso GabcikovoNagymaros, cuja decisão foi proferida em 1997, nos seguintes termos:

A proteção do meio ambiente é [...] uma parte vital da doutrina contemporânea dos direitos humanos, por ser sine qua non para muitos direitos humanos como o direito a saúde e o próprio direito a vida. Não é necessário elaborar muito acerca disso, já que o dano ao meio ambiente pode prejudicar e minar todos os direitos humanos expressos na Declaração Universal e em outros instrumentos de direitos humanos. ${ }^{62}$

Nesse sentido, temos que um dano ao meio ambiente impulsiona o Direito Ambiental (Internacional) e o Direito Internacional dos Direitos Humanos a trabalharem juntos para solucionar o problema, enquanto um verdadeiro esverdeamento do sistema jurídico, o qual se reforça na tentativa de evitar que outras perdas ecológicas e naturais possam emergir - quadro este que corrobora diretamente para o nascimento do Direito Humano Ambiental, haja vista a multiplicação de documentos e demais legislações lutando para a sua tutela.

\section{DIREITO HUMANO AMBIENTAL COMO REGRA COSTUMEIRA}

O Direito Humano Ambiental não é um direito positivado na esfera internacional de forma evidente e inexorável, tal como o Direito a Vida ou o Direito a Saúde, os quais são encontrados explicitamente em diversos documentos internacionais e carregam em si claras prescrições para que os Estados cumpram, de modo a garantir esses direitos aos indivíduos situados dentro de seus territórios, sob pena de responsabilização internacional. O Direito Humano Ambiental, na verdade, é uma construção consuetudinária, que advém da própria evolução histórica da sociedade e da necessidade de tutelar esse bem público (baldios) que sofre constantes interferências do ser humano, e sem o qual a continuidade da vida humana (como um todo) estaria ameaçada.

Por essa banda, o Direito Humano Ambiental garante o seu lugar enquanto preceito humano fundamental, a ser protegido por todos os países ao redor do globo, através da sua consagração enquanto regra costumeira, dada a falta de um documento que afirme, no plano internacional, a existência de tal Direito Humano de forma explícita. Contudo, é importante frisar que para o Direito Internacional, uma norma costumeira é tão importante quanto um tratado, sendo considerada igualmente uma fonte primária de Direito,

\footnotetext{
${ }^{61}$ BOSSELMANN, Klaus. Direitos Humanos, Meio Ambiente e Sustentabilidade. In: SARLET, Ingo Wolfgang. Estado Socioambiental e Direitos Fundamentais. Porto Alegre: Livraria do Advogado, 2010. p. 75.

${ }^{62}$ CIJ. Gabcikovo-Nagymaros Case (Hungary vs. Slovakia). Sep. Opinion Weeramantry. 1997. p. 4.
} 
as quais regulam o comportamento da sociedade internacional, criando prescrições que devem ser por eles seguidas. ${ }^{63}$

A norma consuetudinária, em Direito Internacional, revela-se através da prática uniforme e constante de uma determinada conduta pelos Estados, bem como do próprio comportamento dos mesmos no sentido de espontaneamente seguir uma regra não escrita, por entender que ela é moralmente correta e que segue os anseios da sociedade contemporânea. ${ }^{64}$ Nesse viés, como bem ressalta o renomado professor Malcolm Shaw, a regra costumeira elucida que os Estados não restringem o seu comportamento apenas com base no que é legalmente requerido (positivado), mas também o fazem por meio da sua conviç̧ão, que é elucidada por repetidas condutas em um determinado sentido. $^{65}$

Por conseguinte, o nascimento do Direito Humano Ambiental, enquanto fonte de Direito que cria obrigações para a comunidade internacional, ocorre com a crescente preocupação para com o meio ambiente no plano global - inquietações estas que se manifestam no plano da ONU em diversos documentos firmados ao longo dos anos, seja ao final de conferências internacionais ou em reuniões da própria Assembleia Geral, as quais efetivamente aproximam o Direito Ambiental Internacional e o Direito Internacional dos Direitos Humanos, para solucionar o problema da Tragédia dos Baldios, tutelando o meio ambiente de modo a garantir uma vida saudável e ecologicamente equilibrada à pessoa humana.

E a primeira tentativa de integrar esses campos, motivando a criação de um Direito Humano Ambiental, ocorreu na Convenção de Estocolmo de junho de 1972, também chamada de Conferência das Nações Unidas sobre o Meio Ambiente Humano. ${ }^{66}$ Esse encontro, com sucesso, afirmou a relação existente entre o Direito Ambiental e os Direitos Humanos no documento acordado ao final das discussões, tanto em seu preâmbulo quanto no seu primeiro e segundo princípio. Respectivamente, a Declaração de Estocolmo, como é comumente conhecido esse extrato final da Conferência de 72, asseverou:

O homem é ao mesmo tempo obra e construtor do meio ambiente que o cerca, o qual the dá sustento material e lhe oferece oportunidade para desenvolver-se intelectual, moral, social e espiritualmente. [...] Os dois aspectos do meio ambiente humano, o natural e o artificial, são essenciais

\footnotetext{
${ }^{63}$ ONU. Estatuto da Corte Internacional de Justiça. 1945. Artigo 38; REZEK, J. Francisco. Direito Internacional Público: Curso Elementar. 10. ed., São Paulo: Saraiva, 2005. p. 120.

${ }^{64}$ AMARAL JUNIOR, Alberto. Curso de Direito Internacional Público. 4. ed., São Paulo: Atlas, 2013. p. 130-132.

${ }^{65}$ SHAW, Malcolm. International Law. 5. ed., Cambridge: Cambridge University Press, 2003. p. 69.

${ }^{66}$ A AGNU decide sobre a Convenção de Estocolmo de 1972 ainda em 1968, por meio da Resolução 2398 tomada na $23^{a}$ sessão plenária, a qual faz menções diretas acerca de problemas ao ambiente humano, clamando por um uso racional da biosfera, tanto em nível domestico quanto internacional. Cf. AGNU. Resolução 2398 (XXIII). 1968. [U.N. Doc. A/RES/7218 (1968)]. Preâmbulo.
} 
para o bem-estar do homem e para o gozo dos direitos humanos fundamentais, inclusive o direito à vida mesma (preâmbulo - 1).

A proteção e o melhoramento do meio ambiente humano é uma questão fundamental que afeta o bem-estar dos povos e o desenvolvimento econômico do mundo inteiro, um desejo urgente dos povos de todo o mundo e um dever de todos os governos (preâmbulo - 2).

$\mathrm{O}$ homem tem o direito fundamental à liberdade, à igualdade e ao desfrute de condições de vida adequadas em um meio ambiente de qualidade tal que lhe permita levar uma vida digna e gozar de bem-estar, tendo a solene obrigação de proteger e melhorar o meio ambiente para as gerações presentes e futuras (princípio I).

Os recursos naturais da terra incluídos o ar, a água, a terra, a flora e a fauna e especialmente amostras representativas dos ecossistemas naturais devem ser preservados em benefício das gerações presentes e futuras, mediante uma cuidadosa planificação ou ordenamento (princípio II). ${ }^{67}$

Desta feita, da Declaração de Estocolmo é interessante observar a formulação do meio ambiente sadio e ecologicamente equilibrado como condição prévia essencial para a vida e o bem-estar humano, e para o consequente gozo completo dos direitos básicos, não só da geração presente, mas também das vindouras, o que, noutros termos, torna necessário preservar e melhorar o ecossistema terrestre, para evitar transgressões aos direitos considerados fundamentais da pessoa. Não obstante a manifesta evolução quanto à relação entre os Direitos Humanos e o Meio Ambiente em um texto internacional, Edson Ferreira de Carvalho ressalta pertinentemente que "o texto da Declaração de Estocolmo não estabeleceu o direito humano ao meio ambiente, mas expressou a ideia em termos de direitos humanos", o que já é um avanço significativo para a criação do Direito Humano Ambiental. ${ }^{68}$

Interessante notar a posição de Dinah Shelton acerca desse fato, vez que a autora destaca que essa interface só foi possível por força de os trabalhos preparatórios para aquela Conferência terem ocorrido na mesma época da Conferência das Nações Unidas sobre Direitos Humanos no Teerã, em 1968. Isso, pois, foi nessa reunião que foi "proclamada a interpendência e a indivisibilidade de todos os Direitos Humanos, deixando uma abertura para a consideração de temas complexos como direitos ambientais". ${ }^{69}$

$\mathrm{Na}$ continuação para a afirmação histórica e positiva do Direito Humano Ambiental, o segundo documento que aborda essa temática foi o Relatório da Comissão Mundial das Nações Unidas para o Meio Ambiente e Desenvolvimento, mais conhecido como "Nosso Futuro Comum", publicado em 1987, o qual afirma

${ }^{67}$ ONU. Declaração de Estocolmo. 1972. [U.N. Doc. A/CONF.48/14 (1972)]. Preâmbulo (itens 1 e 2) e Artigos 1 e 2.

${ }^{68}$ CARVALHO. Op. Cit., p. 168.

${ }^{69}$ SHELTON, Dinah. Human Rights and the Environment: what specific environmental rights have been recognized? Denver Journal of International Law and Policy. Denver, v. 35, $n^{\circ} 1$, p. 129-171, 2006. p. 129. 
ser necessário providenciar a todo ser humano um ambiente adequado à saúde e ao bem-estar por ser seu direto fundamental. ${ }^{70}$

Na sequência, a Subcomissão de Prevenção da Discriminação e Proteção das Minorias da ONU referiu-se sobre o entrelaçamento dessas áreas, o que demonstra a sua crescente propagação na comunidade internacional ${ }^{71}$ Ela adotou duas Resoluções importantíssimas, quais sejam, a de número 1988/26 e a $1990 / 7$.

A primeira abordou a questão do movimento e do descarte de produtos tóxicos e perigosos, principalmente no ambiente africano, uma vez que tais rejeitos ameaça(va)m "os direitos básicos dos homens, como o direito a vida, o direito a viver em um ambiente sano e saudável e o direito a saúde", gerando um grande debate acerca da relação entre direitos humanos e meio ambiente. ${ }^{72}$ A segunda, ao seu turno, considerando as discussões que brotavam nesse foro, referia-se a necessidades de estudos sobre as articulações desses direitos. $^{73}$

Assim, por força dessas dúvidas que pairavam nas querelas no domínio da ONU, a Comissão de Direitos Humanos, órgão de capacidade consultiva e destinado a proteção desses direitos, ${ }^{74}$ aprovou uma série de resoluções no decorrer do ano de 1990 para avaliar as articulações dessas áreas, concluindo que haviam sim interconexões íntimas entre elas, principalmente no que tange a preservação ambiental e a promoção de direitos fundamentais. ${ }^{75}$

Após, foi a vez da AGNU especificamente tratar desta vinculação entre Direitos Humanos e Meio Ambiente, por força da crescente degradação ambiental vislumbrada. Na ocasião da $68^{\mathrm{a}}$ reunião plenária (1990) a Assembleia aprovou a resolução de número 45/94, reafirmando os mandamentos da Declaração de 1972 e confirmando a necessidade de um meio ambiente

\footnotetext{
${ }^{70}$ Esse documento foi recepcionado pela AGNU, em 1987 através da Resolução 42/187 [U.N. Doc. A/42/427 (1987)]; WORLD COMMISSION ON ENVIRONMENT AND DEVELOPMENT. Our Common Future. Oxford: Oxford University Press, 1987. p. 286 (Anexo 1, Princípio 1).

${ }^{71}$ Essa subcomissão era atrelada a antiga Comissão de Direitos Humanos da ONU.

${ }^{72}$ SUBCOMMISSION TO THE MINORITIES. Resolution 1988/26. 1988. Preâmbulo. (Deu origem à Resolução 1989/42 de 1989 da Comissão de Direitos Humanos, à Convenção da Basiléia de também de 1989 e, finalmente, à Resolução 43.25 de 1990 da World Health Assembly).

${ }^{73}$ SUBCOMMISSION TO THE MINORITIES. Resolution 1990/7. 1990. Preâmbulo.

${ }^{74}$ Insta dizer que a Comissão era ligada ao Conselho Econômico e Social, cujo objetivo pairava na proteção dos direitos humanos, por intermédio de estudos, recomendações e, até mesmo, investigações de violações feitas por intermédio de comunicações. Situações estas que analisava e repassava à AGNU e ao Conselho Econômico Social o seu relatório. Vale dizer que, em 15 de março de 2006, foi criado o Conselho de Direitos Humanos, o qual substituíra esta Comissão. Cf. COMPARATO. Op. Cit., p. 217.

${ }^{75}$ COMISSÃO DE DIREITOS HUMANOS. Resolução 1990/4. 1990. Requereu estudos aprofundados sobre as conexões entre Direitos Humanos e meio ambiente; COMISSÃO DE DIREITOS HUMANOS. Resolução 1990/41. 1990. Reafirmou a conexão entre o meio ambiente e os Direitos Humanos; COMISSÃO DE DIREITOS HUMANOS. Resolução 1990/43. 1990. Apesar de abordar a questão do lixo tóxico, confirmou a existência de "certos produtos que ameaçam os Direitos Humanos básicos como o direito a melhores padrões de saúde, incluindo seus aspectos ambientais".
} 
saudável para o bem-estar dos indivíduos, posto que através dele seria possível a plena satisfação/realização dos direitos humanos por todos, no presente e no futuro. ${ }^{76}$

O próximo passo para a construção do Direito Humano Ambiental ocorreu em 1994, com a reunião de um grupo de especialistas em Genebra para construir um documento a ser recomendado à $\mathrm{ONU}$, por força de um convite efetuado pela Relatora Especial Fatma Ksentini da Subcomissão de Prevenção da Discriminação e Proteção das Minorias, o qual abordaria uma série de Princípios de Direitos Humanos e Meio Ambiente. ${ }^{77}$ Como anota Edson Ferreira de Carvalho, o preâmbulo da minuta assenta-se no Direito Internacional dos Direitos Humanos e no Direito Ambiental Internacional, estabelecendo como seu primeiro princípio, a interdependência dos Direitos Humanos e do direito ao meio ambiente ecologicamente saudável; e como segundo, a própria dimensão ambiental como direito humano. ${ }^{78}$

Nesse sentido, consideráveis avanços foram efetuados sob os auspícios da ONU, os quais, contudo, não se encerram no campo das declarações, dado que algumas convenções internacionais e regionais igualmente fomentaram a construção do Direito Humano Ambiental. Desde uma perspectiva cronológica, são elas: a Carta Africana dos Direitos Humanos e dos Povos de 1981, o Protocolo de São Salvador de 1988, a Convenção Internacional sobre os Direitos da Criança de 1989 e a Convenção sobre Povos Indígenas e Tribais da OIT, igualmente de 1989.

A Carta Africana dos Direitos Humanos e dos Povos de 1981, documento de ordem regional que contém deveres voltados aos indivíduos daquele continente, estabelece explicitamente, em seu artigo 24, que "todos os povos têm direito a um meio ambiente geral satisfatório, propício ao seu desenvolvimento". ${ }^{7}$ O Protocolo de São Salvador, de outra banda, é um documento adicional à Convenção Americana de Direitos Humanos, datado de 1988, cuja matéria basicamente detinha-se aos direitos econômicos, sociais e culturais - adotando

\footnotetext{
${ }^{76}$ AGNU. Resolução 45/94. 1990. [U.N. Doc. A/RES/45/94 (1990)]. Preâmbulo.

${ }^{77}$ Mister dizer que embora a Conferência das Nações Unidas em prol do Meio Ambiente e do Desenvolvimento de 1992 tenha sido um sucesso no que tange a afirmação do desenvolvimento sustentável, como bem adverte o professor Alan Boyle, a interconexão entre Direito Humano e meio ambiente não foi discutida $A$ única menção na Declaração do Rio acerca disso, estava no princípio de número um, na referência ao direito que o ser humano possui à uma vida produtiva em harmonia com a natureza - o que foi considerado um atraso nesta questão, dada as fervorosas discussões em outros comitês da ONU. BOYLE, Alan. Human Rights or Environmental Rights? A Reassessment. Fordham Environmental Law Review. New York, v. 18, p. 471-508, 2007. p. 473.

${ }^{78}$ CARVALHO, Edson Ferreira. Meio Ambiente e Direitos Humanos. 2. ed., Curitiba: Juruá, 2011. p. $178-179$.

79 OUA. Carta Africana dos Direitos Humanos e dos Povos. 1981. Artigo 24. Veja também: Esse enfoque foi relembrado pela Comissão Africana de Humanos quando se manifestou da contaminação causada pela extração do petróleo na água, no solo e no ar na região dominada pelos indígenas Ogoni, na Nigéria, os quais foram afetados em sua intimidade. AFRICAN COMISSION ON HUMAN RIGHTS AND PEOPLES' RIGHTS. Communication $n^{\circ}$ 155/96 (Ogoni Case: Social and Economic Rights Action Centre and the Centre for Economic and Social Rights v. Nigeria). 2002.
} 
um direito específico ao meio ambiente sadio, como forma de garantir seus direitos básicos. ${ }^{80}$

De forma contínua, após esse fomento nos planos regionais, realçando a construção de um sentido internacional em prol da proteção do meio ambiente para resguardar os interesses do homem, volta-se ao panorama global, vez que a Convenção sobre os Direitos da Criança de 1989 trouxe para um documento escrito vinculante de ordem global, pela primeira vez, as preocupações acerca da situação do meio ambiente e o seu impacto na saúde das crianças. Prescreve o artigo 24 nas alíneas 'c' e 'e' do parágrafo segundo, um direito alusivo ao Direito Humano Ambiental destas, posto que a degradação ambiental poderia impactar negativamente à pessoa humana. ${ }^{81}$ Inclusive, a Comissão sobre os Direitos das Crianças, criada com intuito de assegurar a correta aplicação desse instrumento internacional, já recomendou em duas oportunidades a tomada de medidas para contornar o problema ambiental em determinados Estados com base no referido artigo, por infringir os direitos básicos das crianças. ${ }^{82}$

No que compete a Convenção sobre Povos Indígenas e Tribais em Países Independentes de 1989, também conhecida como Convenção no 169 , a comunidade internacional manifestou-se, mais uma vez, em uma matéria específica acerca de um Direito Humano Ambiental. Abalizada na ideia de que os povos indígenas possuem uma intrínseca conexão para com o meio ambiente, dada as suas origens, dependendo dos recursos naturais para a sua subsistência, a OIT convenciona com o fito de resguardar esses direitos, pois fundamentais para a mantença de tais grupos. ${ }^{83}$

\footnotetext{
${ }^{80}$ OEA. Protocolo de São Salvador. Protocolo Adicional à Convenção Americana sobre Direitos Humanos em matéria de Direitos Econômicos, Sociais e Culturais. 1988. Artigo 11 - Direito a um meio ambiente sadio: (a) Toda pessoa tem direito a viver em meio ambiente sadio e a contar com os serviços públicos básicos; (b) Os Estados Partes promoverão a proteção preservação e melhoramento do meio ambiente. Veja também: Esse enfoque foi relembrado pela Comissão Inter-Americana de Direitos Humanos da OEA, quando reportando sobre a situação da poluição por petróleo no Equador, a qual ameaçava a vida dos indivíduos. INTERAMERICAN COMISSION ON HUMAN RIGHTS. Report on the Situation of Human Rights in Ecuador. 1997. [OEA Doc. $\mathrm{n}^{\circ}$ Ser.L/V/II.96.]. Doc. 10, Rev. 1, p. 92.

${ }^{81}$ ONU. Convenção sobre o Direito das Crianças. 1989. Artigo 24(2) - Os Estados-Partes garantirão a plena aplicação desse direito e, em especial, adotarão as medidas apropriadas com vistas a: (c) combater as doenças e a desnutrição dentro do contexto dos cuidados básicos de saúde mediante, inter alia, a aplicação de tecnologia disponível e o fornecimento de alimentos nutritivos e de água potável, tendo em vista os perigos e riscos da poluição ambiental; (e) assegurar que todos os setores da sociedade, e em especial os pais e as crianças, conheçam os princípios básicos de saúde e nutrição das crianças, as vantagens da amamentação, da higiene e do saneamento ambiental e das medidas de prevenção de acidentes, e tenham acesso à educação pertinente e recebam apoio para a aplicação desses conhecimentos.

${ }^{82}$ ALFREDSSON, Gudmundur. Human Rights and the Environment. In: LEARY, David; PISUPATI, Balakrishna (edts.). The Future of International Environmental Law. New York: UN University Press, 2010. p. 129-130.

${ }^{83}$ OIT. Convenção $n^{\circ} 169$. Convenção sobre Povos Indígenas e Tribais em Países Independentes. 1989. Artigos 4(1) - refere-se a medidas para resguardar o meio ambiente; 7(3)(4) - refere-se a medidas para evitar o impacto ambiental de certas ações, bem como o dever de proteger o bem
} 
$\mathrm{Na}$ década de 1990, outro importante passo correu no âmbito da Organização das Nações Unidas para a Educação, a Ciência e a Cultura ('UNESCO'). Edificada com propósito de contribuir para a paz e segurança no globo mediante a educação, a ciência, a cultura e as comunicações entre os povos, essa organização já vinha advogando para um direito ao meio ambiente, relacionando-o com as necessidades humanas, todavia, foi somente em 1997, por meio da Declaração sobre as Responsabilidades das Presentes Gerações para com as Futuras, que ela explicitamente abordou a dicotomia do Direito Humano Ambiental. O artigo quinto, especificamente, confirma a necessidade de proteger o meio ambiente em prol das gerações vindouras, bem como da própria saúde e desenvolvimento das presentes gerações, uma vez que é determinante para a sua própria existência enquanto ser humano. ${ }^{84}$

Anota de forma brilhante Edson Ferreira de Carvalho que a linguagem contida nessa Declaração já propagava o meio ambiente como direito da humanidade. Até mesmo, ela teria influenciado uma série de reuniões posteriores da UNESCO, dentre as quais, o Seminário Internacional de Biskaia em 1999 destaca-se, afirmando em seu texto final que toda pessoa teria o direito, individualmente ou em associação, de desfrutar um ambiente saudável e ecologicamente equilibrado. ${ }^{85}$

Destarte, com a leitura desses documentos, resta claro que ao longo dos anos, a comunidade internacional interessou-se cada vez mais nas conexões entre meio ambiente e Direitos Humanos, percebendo que a vida humana depende da qualidade ambiental para que seja desenvolvida dignamente, reafirmando tal posição em diversos textos internacionais, os quais figuram como a comprovação da opinio juris sive necessitatis - o elemento psicológico do costume internacional que molda o comportamento estatal pela crença de que a conduta realizada é a moralmente correta. ${ }^{86}$

Logo, com a intensa harmonia entre tais searas, torna-se imprescindível a criação de uma regra que garanta a tutela dos indivíduos (frente ao Estado e de forma difusa) para que o ser humano não seja atingido em seu âmago pela degradação ambiental exteriorizada pela Tragédia dos Baldios, que é justamente o Direito Humano Ambiental. Nesse sentido, além do elemento psicológico, outro elemento faz-se necessário para a configuração do costume internacional que é o elemento material, ou seja, a prática contínua e reiterada por parte dos Estados.

ambiental desses povos; 13(2) - refere-se a acepção de 'território indígena/tribal', o qual seria toda a região, incluindo os seus recursos naturais; e 15(1)(2) - referem-se ao direito desses povos ao meio ambiente das regiões habitadas por eles, bem como a necessidade de consulta sempre que o governo desejasse agir em tal região.

${ }^{84}$ UNESCO. Declaration on the Responsibilities of the Present Generations towards Future Generations. 1997. Artigo 5.

${ }^{85}$ CARVALHO. Op. Cit., p. 180. Veja também: UNESCO. Declaration of Biskaia on the Right to the Environment. 1999. Artigo 1. Disponível em: <http://unesdoc.unesco.org/images/0011/001173/ 117321e.pdf>. Acesso em 15 jan. 2012.

${ }^{86}$ SHAW. Op. Cit., p. 71. 
Conforme assevera Malcolm Shaw, a conduta desses entes de direito internacional é normalmente observada por meio dos seus próprios sistemas domésticos, aonde é possível visualizar se o Estado concorda com o crescente entendimento internacional do que é moralmente adequado. ${ }^{87}$ Portanto, é interessante notar que ao lado das declarações e convenções firmadas desde meados de 1970 no âmbito internacional, inúmeros países passaram a legislar sobre a proteção ambiental, inclusive, considerando o resguardo do meio ambiente enquanto direito constitucional - fato este que é extremamente importante para a classificação desse direito enquanto um costume internacional, agregando os seus elementos principais, isto é, a prática reiterada dos Estados à crença da ação moralmente correta.

Em inúmeras Constituições, o meio ambiente é considerado um direito fundamental. São exemplos dessa constitucionalização e da consequente comprovação da prática dos países, o Japão (artigo 25), o Equador (artigos 71 e 72), a Espanha (artigo 45), a Itália (artigo 9), a Colômbia (artigos 79 a 82), a Rússia (artigos 42 e 58), as Filipinas (artigo 16), a Suíça (artigos 73 a 80), a Índia (artigo 48 e 51), a Grécia (artigo 24), a França (adendo constitucional para o ambiente), a Bélgica (artigo 23), a Holanda (artigo 21), a China (artigos 9 e 26), o México (artigo 4), a Alemanha (artigo 20), Portugal (artigo 66), a África do Sul (artigo 24) e o Brasil (artigo 225) - entre tantas.

Por isso que no seio de todas essas discussões é que emerge o próprio Direito Humano Ambiental, como produto de uma percepção da aldeia global das necessidades de meios de combate a degradação. Não obstante a inexistência de um tratado internacional específico para definir e tutelar o meio ambiente enquanto Direito Humano, é visível que no âmbito internacional esse novo direito já afirmou-se enquanto costume internacional.

Afinal, as inúmeras declarações e convenções que abordaram essa matéria no decorrer dos anos estabeleceram um entendimento mundial comum acerca da necessidade de evitar a degradação ambiental, por todos os impactos negativos que ela oferece ao ser humano. Além disso, por força da enorme quantidade de ratificações às convenções internacionais e regionais (vinculantes), e da própria constitucionalização desse direito nos planos domésticos, não há como negar a existência de uma prática consolidada e de consciência (conviç̧ão) coletiva internacional de que assim deve-se proceder por ser necessário, correto, justo e de bom direito, no tocante a esta matéria.

\footnotetext{
${ }^{87}$ Idem.

${ }^{88}$ MIRANDA, Jorge. Manual de Direito Constitucional. 3. ed., Coimbra: Ed. Coimbra, 2000. p. 533; RAMOS, Erasmo Marcos. Direito Ambiental Comparado. Maringá: Midiograf II, 2009. p. 8; para uma análise extensiva acerca da inserção constitucional de muitos dos países listados, confira: SANTOS JUNIOR, Antônio. Meio Ambiente como Direito Fundamental. Dissertação de Mestrado. Curso de Pós Graduação em Direito Econômico e Social. Curitiba: PUCPR, fev. 2007. $129 \mathrm{p}$.
} 


\section{CONSIDERAÇÕES FINAIS}

Por isso, afirma-se que o Direito Humano Ambiental verdadeiramente existe, sendo considerada uma normativa vinculante no plano internacional, visto que está, de certa forma, "positivada" nas entranhas da comunidade, o que produz efeitos diretos a serem cumpridos por todos os Estados, como uma verdadeira obrigação erga omnes ${ }^{89}$ mesmo não havendo um documento único que assim ateste. Particularmente nesse condão, a $\mathrm{CIJ}$ já se manifestou em sua Opinião Consultiva sobre o Uso de Armas Nucleares de 1996:

O meio ambiente não é uma abstração, mas representa um espaço vivo, a qualidade de vida e a saúde dos seres humanos, incluindo as gerações futuras. A existência de uma obrigação geral que vincule os Estados, fazendo-os garantir que as atividades dentro de sua jurisdição respeitem o meio ambiente [...] faz parte do corpo do direito internacional. ${ }^{90}$

Assim, há um interesse coletivo na sociedade mundial em reconhecer esse novo direito fundamental, dada as modificações que emergiram com a degradação ambiental exteriorizada pela Tragédia na metade do século XX, tal como advoga a fundamentação historicista dos Direitos Humanos. O reconhecimento por meio de tratados e convenções, de outra banda, é imperioso por tornar mais perceptíveis esses direitos aos olhos dos diversos atores na órbita internacional e doméstica - afirmando-os perante a todos os sujeitos.

Essas noveis formulações, por afetarem não só a uma comunidade em um determinado Estado, sendo genuinamente trasnfronteiriças, e por despertarem um desejo de preservação, fomentando novas práticas, como as sustentáveis e esverdeadas, acabam por classificar o Direito Humano Ambiental como de terceira dimensão - abarcando toda a aldeia global e cultivando o espírito de cooperação e solidariedade entre os povos. Afinal, como bem assevera Edson Ferreira de Carvalho, "da mesma forma que a violação massiva de direitos humanos" em conflitos armados ocorre, "certos impactos ambientais [igualmente] constituem uma ameaça à paz e ao desenvolvimento", posto que "ameaçam não só indivíduos e grupos dentro das fronteiras nacionais, mas também, toda humanidade". ${ }^{91}$

De modo inovador, ao fim e ao cabo, resta inserido nos liames da sociedade esse direito, clamando por uma real efetivação no século XXI, não só pela sua imperiosidade para o bem-estar e o desenvolvimento de cada indivíduo, seja da atual ou da futura geração, mas igualmente porque é um direito fundamental que todos os seres humanos tem em si, o qual compartilham.

\footnotetext{
${ }^{89}$ Entende-se por normas erga omnes aquelas normas que geram efeitos para todos os Estados. RAGAZZI, Maurizio. The Concept of International Obligations erga omnes. New York: Oxford Monographs in International Law, 1997. p. 1 e 17.

${ }^{90} \mathrm{ClJ}$. Legality of the Threat or Use of Nuclear Weapons. Advisory Opinion. 1996. Rep. 226, para. 29.

${ }^{91}$ CARVALHO. Op. Cit., p. 159.
} 


\section{REFERÊNCIAS BIBLIOGRÁFICAS}

AFRICAN COMISSION ON HUMAN RIGHTS AND PEOPLES' RIGHTS. Communication $n^{\circ}$ 155/96 (Ogoni Case: Social and Economic Rights Action Centre and the Centre for Economic and Social Rights v. Nigeria). 2002.

AGNU. Resolução 217 A (III). 1948.

AGNU. Resolução 2398 (XXIII). 1968.

AGNU. Resolução 42/187. 1987.

AGNU. Resolução 45/94. 1990.

ALEMANHA. Constituição de Weimar. 1919.

ALFREDSSON, Gudmundur. Human Rights and the Environment. In: LEARY, David; PISUPATI, Balakrishna (edts.). The Future of International Environmental Law. New York: UN University Press, 2010.

AMARAL JUNIOR, Alberto. Curso de Direito Internacional Público. 4. ed., São Paulo: Atlas, 2013.

ANDRADE, Helder N. Hegel e Vico: o sentido da história. Argumentos - Revista de Filosofia. Fortaleza, a. 1, no 1, p. 28-35, 2009.

ANDRADE, José Carlos Vieira de. Os Direitos Fundamentais na Constituição Portuguesa de 1976. Coimbra: Livraria Almedina, 1987.

ANNONI, Danielle. O Legado da Declaração Universal dos Direitos Humanos das Nações Unidas. Revista lus Gentium. Curitiba. A. 1, nº 2, p. 73-86, jul./dez. 2007.

BAPTISTA, Zulmira M. de Castro. O Direito Ambiental Internacional: políticas e consequências. São Paulo: Editrora Pillares, 2005.

BIELEFELDT, Heiner. Filosofia dos Direitos Humanos. Trad.Dankwart Bernsmüller. São Leopoldo: UNISINOS, 2000.

BILLIER, Jean-Cassien; MARYOLI, Aglaé. A História da Filosofia do Direito. Barueri: Manole, 2005.

BOBBIO, Norberto. A Era dos Direitos. Trad. Carlos Nelson Coutinho. Rio de Janeiro: Campus, 1992.

BOBBIO, Norberto. Elogio da Serenidade e outros Escritos Morais. São Paulo: UNESP, 2000.

BOBBIO, Norberto. O Problema da Guerra e as Vias da Paz. São Paulo: UNESP, 2003.

BONAVIDES, Paulo. Curso de Direito Constitucional. 11. ed., São Paulo: Malheiros, 2001.

BOSSELMANN, Klaus. Direitos Humanos, Meio Ambiente e Sustentabilidade. In: SARLET, Ingo Wolfgang. Estado Socioambiental e Direitos Fundamentais. Porto Alegre: Livraria do Advogado, 2010.

BOYLE, Alan. Human Rights or Environmental Rights? A Reassessment. Fordham Environmental Law Review. New York, v. 18, p. 471-508, 2007.

BUERGENTHAL, Thomas. International Human Rights in a Nutshell. 3. ed., New York: West Publishing, 2002.

CANOTILHO, José J. Gomes. Juricidização da Ecologia ou Ecologização do Direito. Revista Jurídica do Urbanismo e do Ambiente. Coimbra, nº 4, p. 69-79, dez. 1995. 
CANÇADO TRINDADE, Antônio A. Direitos Humanos e Meio Ambiente: paralelo dos sistemas de proteção internacional. Porto Alegre: SAFE, 1993.

CARDOSO, Tatiana de A. F. Direitos Humanos no Século XXI: a tutela das novas categorias e a sua (não) efetividade na era do risco. Anais da III Mostra de Pesquisa de Pós-Graduação - MIC. Passo Fundo: IMED, 2010.

CARDOSO, Tatiana de A. F. O Direito Internacional dos Direitos Humanos e a sua Relação com o Direito Internacional Humanitário. Anais do V SEPesq: comunicações de Pós-Graduação. Canoas: UniRitter, 2009.

CARVALHO, Edson Ferreira. Meio Ambiente e Direitos Humanos. 2. ed., Curitiba: Juruá, 2011.

CIJ. Estatuto da Corte Internacional. 1945.

ClJ. Gabcikovo-Nagymaros Case (Hungary vs. Slovakia). App. Memorial (Hungary), 1993.

ClJ. Gabcikovo-Nagymaros Case (Hungary vs. Slovakia). Sep. Opinion Weeramantry. 1997.

CIJ. Legality of the Threat or Use of Nuclear Weapons. Advisory Opinion. 1996.

COMISSÃO DE DIREITOS HUMANOS. Resolução 1990/4. 1990.

COMISSÃO DE DIREITOS HUMANOS. Resolução 1990/41. 1990.

COMISSÃO DE DIREITOS HUMANOS. Resolução 1990/43. 1990.

COMPARATO, Fábio Konder. A Afirmação Histórica dos Direitos Humanos. 5. ed., São Paulo: Saraiva, 2007.

DOUZINAS, Costas. The End of Human Rights. Portland: Hart Publishing, 2000.

ENGELMANN, Wilson. Direito Natural, Ética e Hermenêutica. Porto Alegre: Livraria do Advogado, 2007.

ESTADOS UNIDOS. Carta da Virgínia. 1776.

ESTADOS UNIDOS. Constituição Federal. 1787.

ESTADOS UNIDOS. Declaração de Independência. 1776.

FERREIRA FILHO, Manoel Gonçalves. Direitos Humanos Fundamentais. 13. ed., São Paulo: Saraiva, 2011.

FERREIRA FILHO, Manuel Gonçalves. Curso de Direito Constitucional. 24. ed., São Paulo: Saraiva, 1997.

FINNIS, John. Natural Law and Natural Rights. Oxford: Oxford University Press, 1980.

FRANÇA. Declaração dos Direitos do Homem e do Cidadão. 1789.

FURTADO, Fernanda Andrade. Direitos Humanos, Ética Ambiental e o Conflito entre Direitos Fundamentais. Revista da Fundação Escola Superior do Ministério Público do Distrito Federal e Territórios. Brasília, a. 11, p. 50-110, set. 2003.

GOMES, Carla Amado. O Ambiente como Objecto e os Objectos do Direito do Ambiente. Disponível em: <http://egov.ufsc.br/portal/sites/default/files/anexos/19332-19333-1-PB.pdf>. Acesso em 10 mar. 2013.

GUERRA, Sidney. Direito Ambiental Internacional. Rio de Janeiro: Freitas Bastos, 2006. HARDIN, Garret. Tragedy of the Commons. Science. v. 162, n 3859, p. 1243-1248, dec. 1968. 
HEGEL, Georg. A Razão na História. São Paulo: Centauro, 2001.

HENKIN, Louis. International Law and the Behavior of Nations. Recueil des Cours de l'Academie de Droit International. Hague, v. 114, no 1, p. 171-279, 1965.

INGLATERRA. Bill Of Rights. 1688.

INGLATERRA. Lei de Habeas Corpus. 1679.

INGLATERRA. Petition Of Right. 1628.

INTERAMERICAN COMISSION ON HUMAN RIGHTS. Report on the Situation of Human Rights in Ecuador. 1997.

KISHI, Sandra Akemi S. A Proteção da Biodiversidade: um direito humano fundamental. In Desafios do Direito Ambiental no Século XXI: estudos em homenagem a Paulo Affonso Leme Machado. São Paulo: Malheiros/IEDC, 2005.

KISS, Alexander; SHELTON, Dinah. International Environemntal Law. New York: Transnational Publisher, 2000.

KISS, Alexandre. Direito Internacional do Ambiente. Lisboa: Centro de Estudos Jurídicos, 1996.

LEWANDOWSKI, Enrique Ricardo. Proteção dos Direitos Humanos na Ordem Interna e Internacional. Rio de Janeiro: Forense, 1984.

LUCAS, Douglas César. Os Direitos Humanos como Limite à Soberania Estatal: Para uma cultura político-jurídica global de responsabilidades. In MENEZES, Wagner (Coord.). Estudos de Direito Internacional. Vol. IX. Curitiba: Juruá, 2007.

MAGALHÃES, José Luiz Quadros de. Direitos Humanos: sua história, sua garantia e a questão da indivisibilidade. São Paulo: Juarez de Oliveira, 2000.

MALONE, Linda A. International Human Rights. St. Paul: West Group, 2003.

MYERS, Norman. Environmental Refugees: a growing phenomenon of the 21 century. Philosophical Transactions of the Royal Society. v. 357, p. 609-613, abr. 2002.

MAZZUOLI, Valério de O.; TEIXEIRA, Gustavo de Faria. O Greening do Sistema Interamericano de Direitos Humanos. Revista Científica Sensus: Direito. Manaus, $n^{\circ} 5$, v. 2, p. 1-21, jul./dez. 2012. p. 7.

MEXICO. Constituição Federal. 1917.

MIGOTO FILHO, Tadeu; PINHEIRO, Ana Cláudia. Enfoque Ambiental dos Direitos Humanos. In: MENEZES, Wagner (Coord.). Estudos de Direito Internacional. Vol. XVI. Curitiba: Juruá, 2009.

MIRANDA, Jorge. Manual de Direito Constitucional. 3. ed., Coimbra: Ed. Coimbra, 2000. MORAIS, José L. Bolzan. As Crises do Estado e da Constituição e a Transformação Espacial dos Direitos Humanos. Porto Alegre: Livraria do Advogado, 2002.

OEA. Protocolo de São Salvador. Protocolo Adicional à Convenção Americana sobre Direitos Humanos em matéria de Direitos Econômicos, Sociais e Culturais. 1988.

OIT. Convenção $n^{\circ}$ 169. Convenção sobre Povos Indígenas e Tribais em Países Independentes. 1989.

OLIVEIRA, Almir de. Curso de Direitos Humanos. Rio de Janeiro: Forense, 2000.

ONU. Las Naciones Unidas y Los Derechos Humanos. Nueva York: ONU, 1979.

ONU. Convenção sobre o Direito das Crianças. 1989.

ONU. Declaração de Estocolmo. 1972. 
OUA. Carta Africana dos Direitos Humanos e dos Povos. 1981.

ONU. Estatuto da Corte Internacional de Justiça. 1945.

PIOVESAN, Flávia. Temas de Direitos Humanos. São Paulo: Max Limonad, 1998.

POJMAN, Louis P. Global Environmental Ethics. Mountain View: Mayfield, 2000.

RAGAZZI, Maurizio. The Concept of International Obligations erga omnes. New York: Oxford Monographs in International Law, 1997.

RAMOS, Erasmo Marcos. Direito Ambiental Comparado. Maringá: Midiograf II, 2009.

REZEK, J. Francisco. Direito Internacional Público: Curso Elementar. 10. ed., São Paulo: Saraiva, 2005.

RITCHIE, Daniel. Edmund Burke: appraisals and applications. New Brunswick: Transaction Publishers, 1990.

SAID, Edward W. Reflexões sobre o Exílio e outros ensaios. São Paulo: Companhia das Letras, 2003.

SAMPAIO, José Adércio L. Direitos Fundamentais: retórica e historicidade. Belo Horizonte: Del Rey, 2004.

SANTOS JUNIOR, Antônio. Meio Ambiente como Direito Fundamental. Dissertação de Mestrado. Curso de Pós Graduação em Direito Econômico e Social. Curitiba: PUCPR, fev. 2007. 129 p.

SARLET, Ingo W. Dignidade da Pessoa Humana e Direitos Fundamentais na Constituição Federal de 1988. Porto Alegre: Livraria do Advogado, 2009.

SCHAFER, Jairo. Classificação dos Direitos Fundamentais: do sistema geracional ao sistema unitário. Porto Alegre: Livraria do Advogado, 2005.

SCHWENCK, Terezinha. Direitos Humanos Ambientais. Disponível em: <http://www.fadipa.br/pdf/schwenck.pdf>. Acesso em 12 mar. 2013.

SCHWARTZ, Bernard. Os Grandes Direitos da Humanidade: "The Bill of Rights". Trad. A. B. Pinheiro de Lemos. Rio de Janeiro: Forense Universitária, 1979.

SHAW, Malcolm. International Law. 5. ed., Cambridge: Cambridge University Press, 2003.

SHELTON, Dinah. Environmental Rights. In: ALSTON, Philip. (ed.). People's Rights. New York: Oxford University Press, 2001.

SHELTON, Dinah. Human Rights and the Environment: what specific environmental rights have been recognized? Denver Journal of International Law and Policy. Denver, v. $35, n^{\circ} 1$, p. $129-171,2006$.

SNIDAL, Duncan. The Politics of Scope: endogenous actors, heterogeneity and institutions. In: KEOHANE, Robert O.; OSTROM, Elinor. Local Commons and Global Interdependence: heterogeneity and cooperation in two domains. London: SAGE Publications, 1995.

SPINK, Mary Jane P. A Saúde na Encruzilhada entre Biopolítica e Bioeconomia. In: RIBEIRO, Maria Auxiliadora; BERNARDES, Jefferson de Souza; LANG, Charles Elias. A Produção na Diversidade: compromissos éticos e políticos em psicologia. São Paulo: Casa do Psicólogo, 2007.

SUBCOMMISSION TO THE MINORITIES. Resolution 1988/26. 1988.

SUBCOMMISSION TO THE MINORITIES. Resolution 1990/7. 1990. 
THOMAS, Brook. The New Historicism and other old-fashioned Topics. Princeton: Princeton University Press, 1991.

UNESCO. Declaration of Biskaia on the Right to the Environment. 1999. Disponível em: <http://unesdoc.unesco.org/images/0011/001173/117321e.pdf>. Acesso em 15 jan. 2012.

UNESCO. Declaration on the Responsibilities of the Present Generations towards Future Generations. 1997.

VAZ, Henrique C. Lima. Escritos de Filosofia IV: Introdução a ética Filosófica 1. São Paulo: Loyola, 2006.

WORLD COMMISSION ON ENVIRONMENT AND DEVELOPMENT. Our Common Future. Oxford: Oxford University Press, 1987. 